\title{
Effectiveness of Online Learning Models for Student Understanding of Subjects in the Civil Engineering Department
}

\author{
Nurmi Frida Dorintan Bertua Pakpahan \\ Department of Civil Engineering, Faculty of Engineering, State University of Surabaya, Surabaya, Indonesia \\ http://dx.doi.org/10.18415/ijmmu.v8i12.3256
}

\begin{abstract}
Covid-19 pandemic has hit Indonesia since February 2020 until now and there is no sign of abating. All activities are carried out at home and are generally carried out through an online system. There is no exception for the teaching and learning process that involves teaching staff and students must implement the learning from home method or study from home. Understanding the principles and factors that affect the effectiveness of applying digital technology in learning is very important. Therefore, the research was carried out with the aim of being able to determine the level of student understanding of the face-to-face learning model in the S1 Building Engineering Education Study Program before the Covid19 pandemic and students' understanding of the online lecture model during the Covid-19 pandemic as well as the effectiveness model of online lectures in courses during the Covid-19 pandemic. This research is a descriptive research study. The object of research is student understanding (academic years 2016/2017, 2017/2018, 2018/2019, 2019/20200), which includes understanding before the Covid-19 pandemic and understanding during the Covid-19 pandemic. The subject of the research is the S1 Building Engineering Education Study Program, Civil Engineering Department, Faculty of Engineering, Unesa. The results of this study are expected to reveal the level of understanding of students with the face-to-face learning model and the level of understanding of students with the online lecture model as well as the effectiveness of the online lecture model in courses during the Covid-19 pandemic.
\end{abstract}

Keywords: Student Understanding;Effectiveness; Face-To-Face Learning Model; Online Lecture Model; Pre-Pandemic; During Pandemic

\section{A. Introduction}

The Covid-19 pandemic outbreak is still ongoing and there are no signs of abating, all activities are generally carried out at home through an online system. Education is no exception, but this does not dampen the enthusiasm for learning of students throughout Indonesia, including the State University of Surabaya (Unesa). The online system used requires students to keep learning and hone academic and nonacademic skills. The development of information and communication technology has become a prima donna choice and has a great influence on the teaching and learning process. Education Observer Ari S. Widodo Poespodihardjo said the teaching staff and students must practice the best possible learning from home method or study from home during the Covid-19 pandemic. Although the face-to-face method is considered the most effective, we must be able to adapt to technological developments and advances and 
be able to apply it as much as possible. Ease of access to technology has been used by teachers to improve the quality of education. Delivered by Keengwe \& Georgina in their research which states that technological developments provide changes to the implementation of teaching and learning (Keengwe \& Georgina, 2012). Information technology can be accepted as a medium in carrying out the educational process, including helping the teaching and learning process, which also involves searching for references and sources of information (Wekke \& Hamid, 2013).

The application of digital technology can have a negative impact on the world of education if its use is not appropriate. Therefore, understanding the principles and factors that affect the effectiveness of digital technology in learning is something that is very important for an educator (Putrawangsa \& Hasanah, 2018). Furthermore, Harto (2018) emphasized that an educator is required to have four competencies in order to be able to use digital technology effectively. First, an educator must understand and be able to use digital technology and its application. Second, having leadership competencies that are able to direct students to have an understanding of technology. Third, have the ability to accurately predict the direction of the turmoil of change and strategic steps to deal with it. Fourth, having competence in controlling oneself from all turbulence of change, and being able to deal with it by generating ideas, innovation, and creativity.

The purpose of this study was to determine the level of effectiveness of the online lecture model for the PTB Undergraduate Study Program course on the readiness of lecturers to carry out online lectures and the level of student ability to understand lecture material during the Covid-19 pandemic at the Civil Engineering Department, Faculty of Engineering, Unesa. The problems to be answered in this study include: What is the level of student understanding in face-to-face learning for PTB Undergraduate Study Program courses before the Covid-19 pandemic?; How is the level of student understanding in online lectures for PTB Undergraduate Study Program subjects during the Covid-19 pandemic?; and How is the effectiveness of the lecture model in the PTB Undergraduate Study Program courses between before the Covid-19 pandemic and during the Covid-19 pandemic?

\section{B. Literature Review}

\section{Lecture Policy in Higher Education During the Covid-19 Pandemic}

In 2014 the Directorate of Learning and Student Affairs, Dirjendikti developed the Indonesian Open and Integrated Online Learning program (PDITT), which was launched on October 15, 2014 by Vice President Boediono. And on 18 September 2016, it became the Online Learning System (SPADA). Indonesia's SPADA program is basically the implementation of the Law of the Republic of Indonesia Number 20 of 2003 concerning the National Education System, Law no. 12 of 2012 concerning Higher Education, and Regulation of the Minister of Education and Culture Number 109 of 2013 was concerning the Implementation of Distance Education in Higher Education. Where in Permendikbud 109 of 2013, states that one of the scopes of distance education is the scope of courses. One of the goals of the SPADA Indonesia program is to increase equitable access to quality learning in higher education. With the online learning system, SPADA Indonesia provides opportunities for students from one particular university to be able to take certain quality courses from other universities and their learning outcomes can be recognized equally by the college where the student is registered.

An electronic letter from the Ministry of Education and Culture regarding Online Learning and Working from Home in the context of preventing the spread of Covid-19 dated March 17, 2020 is an important foundation for universities in Indonesia to implement one of its points which reads, the longest study period for students who should ends in the even semester of 2019/2020, it can be extended by one semester, and the arrangements are left to the head of the university in accordance with local conditions 
and situations. Next, laboratory practicum and field practice can be rescheduled according to the status and conditions in the area.

\section{PTB Undergraduate Study Program Courses Civil Engineering Department, Faculty of Engineering Surabaya State University}

Building Engineering Education, commonly abbreviated as PTB, is one of the educational programs (Prodi) within the Scope of the Civil Engineering Department, Faculty of Engineering, State University of Surabaya (Unesa) which is located on the Unesa Ketintang Campus. Building Engineering Education (PTB) has learning about two basic scientific fields, namely the field of Education and the field of Civil Engineering, where every student is required to have these abilities that are useful for their profession in the future to be able to use science in education and civil construction. At the beginning of the semester of lectures in the PTB study program, starting with General, Education, and Basic Engineering Subjects. General courses include Indonesian, Pancasila Education, Philosophy of Science, English, Religion, and Entrepreneurship. For Educational Subjects include Educational Basics, Educational Psychology, Educational Planning, Educational Evaluation and others. As for the Basic Engineering MK there are Engineering Physics, Engineering Mechanics I-IV, Building Materials Science, Engineering Drawings, Soil Mechanics, Building Construction I-III, Engineering Mathematics, Environmental Engineering, Concrete Technology, Soil Measurement I and II, Engineering Foundations, Soil Measurement (IUT) I and II, Plumbing Practices, Concrete and Wood Structures, RAB, and others. Here learning is given starting from the basics, history, and technological developments of the engineering world every time. PTB students are prepared to become prospective SMK teachers, and are expected to know and master the roots of the civil engineering scientific field that will be taught later.

The courses in each semester are related and continue to be sustainable when moving up to the next semester level. There are prerequisite courses, namely courses that can be taken if the related courses must pass. If the related or related courses and their continuation have not passed, the student cannot take the required courses. An example is, if a student is going to take the IUT II course, then in the previous semester he must have passed the IUT I course. In the PTB study program, every student is required to learn all kinds of scientific provisions that can be applied in the world of work in the future. In addition, students undergo several projects or activities in the field that must be completed. Where the project or field activity takes a lot of time. Field activities carried out include visits to well-known construction companies in Indonesia, Field Work Practices (PKL) to Development Projects or Building Industry Companies, Internships in schools, Field Experience Practices (PPL), KKN, and so on. So, this is a real learning opportunity for students to really experience how to work in the field.

\section{Effectiveness of the Online Lecture Model}

In the midst of the Covid-19 pandemic, our education system must be ready to make a leap to transform online learning for all students and by all teachers. We are entering a new era to build creativity, hone student skills, and improve self-quality by changing systems, perspectives and patterns of our interaction with technology. Learning methods using technology applied by the government are considered a challenge in itself. Online learning should encourage students to be creative, access as much knowledge as possible, and produce work. Not burdening students with piles of assignments. There are many factors that hinder the effectiveness of this online learning, including:

1. Mastery of technology is still low, it must be admitted that not all teachers master technology, especially teachers of the 80s generation who at their time the use of technology was not so visible. Almost the same situation is also experienced by students, not all students are accustomed to using technology in everyday life. In fact, there are still many schools that have technological limitations so that they have to fight over the use of technology tools to support learning and they are not even introduced to technology in learning. 
2. Internet network, online learning cannot be separated from the use of the internet network, the use of the cellular network is sometimes unstable because the location of the residence is still far from the reach of the cellular signal.

3. Cost, the internet network which is very much needed in online learning is a problem in itself. The quota purchased for internet needs has soared.

4. We can see this gap by looking at the differences in internet speed in various regions. People in urban centers often enjoy much faster internet than those living in less developed areas.

Online learning should encourage students to be creative, access as many sources of knowledge as possible, produce works, hone insights and ultimately shape students into lifelong learners. From these challenges, we must dare to take steps to make online learning an opportunity to transform our education. There are several steps that can be considered together in improving our education system, especially regarding online learning:

a. First, all teachers must be able to teach remotely which incidentally must use technology. Increasing the competence of educators at all levels to use distance learning applications is absolutely necessary. Indeed, the number is very large, to ensure that around 3 million teachers in Indonesia have adequate competence in utilizing technology, it is certainly not an easy matter. Minimum ICT competence of level 2 teachers must be realized immediately, including the ability to conduct video conferencing and create online teaching materials. Level 2 is an ideal grouping of ICT competencies for teachers based on the Teacher ICT Competencies Framework by UNESCO. The highest level is level 4 where the teacher is able to become a trainer for other teachers. If the teacher's competence is level 2, then the teacher will be able to prepare a learning system, syllabus and learning methods with digital or online learning patterns. The government does not have to be alone, efforts to collaborate with many online portal providers are very appropriate to be carried out by the Ministry of Education and Culture. However, the leading sector in online learning policy matters must be controlled under the Ministry of Education and Culture.

b. Second, the use of technology is also not arbitrary, there is special knowledge so that the use of technology can be a tool to realize the goals of education, namely Educational technology (TP). Online learning does not only move the face-to-face process using digital applications, accompanied by piling up tasks. Educational technology design systems for online learning to be effective, taking into account specific educational goals. The principles of using technology that must be a reference for teachers in utilizing technology are being able to present difficult and rare facts into the classroom, providing illustrations of natural and scientific phenomena, providing space for students to explore, facilitating interaction and collaboration between students and teachers and students. students, as well as providing individual services without stopping. However, very few teachers understand the above principles. This requires relevant stakeholders, especially Learning Technology Developers, to innovate more and seek learning breakthroughs in times of emergency such as the current Covid-19.

c. Third, online learning patterns must be part of all learning even if only as a complement. The point is that teachers get used to teaching online. The sudden implementation of the online learning system took most educators by surprise. In the future, there must be a system change policy for the implementation of online learning in every subject. Teachers must have implemented technologybased learning according to the capacity and availability of technology. The ministry's initiative to prepare an online learning portal for Rumah Belajar should be supported, although online affairs during the Covid-19 period, which forces students and teachers to carry out activities at home, still need the support of online service providers in Indonesia.

d. Fourth, teachers must have online learning equipment. The minimum ICT equipment that teachers must have is a laptop and video conferencing support tools. The existence of a minimum device that must be owned by teachers needs to be considered together with the district/city, provincial and 
central governments including parents for schools run by the community. There are many fintechs that are engaged in providing assistance in providing technology equipment for students, teachers and schools.

e. Fifth, the digital infrastructure gap between big cities and regions must be bridged with affirmative technology policies for underserved areas. Internet access must be expanded and its bandwidth capacity must also be increased. The Indonesian government has succeeded in building the Palapa Ring communication infrastructure which was inaugurated by President Joko Widodo at the end of 2019 to become the backbone of digital infrastructure from Aceh to Papua. However, the range of access must be expanded so that as many schools, educators and students as possible benefit from it.

\section{Research Method}

\section{Research Objects and Subjects}

The object of the research is the effectiveness of the online lecture model in the Civil Engineering Department S1 PTB Study Program (covering courses in Education and Civil Engineering). The research subjects were students of the PTB Undergraduate Study Program (covering the 2016/2017, 2017/2018, 2018/2019, 2019/2020 academic year) and lecturers in the PTB Undergraduate Study Program, Civil Engineering Department, Faculty of Engineering, State University of Surabaya.

\section{Research Place and Time}

This research was conducted at the PTB Undergraduate Study Program, Civil Engineering Department, Faculty of Engineering, Unesa. The research implementation time is in the form of submitting a proposal until data collection is carried out from May to September 2020. Meanwhile, the learning outcomes data are documents for the even semester of the 2019/2020 academic year. Continued in October and November 2020 carrying out the preparation of progress reports and final reports.

\section{Research Method}

This research is descriptive research. The object of research is the understanding of PTB Undergraduate Study Program students, which includes understanding before the Covid-19 pandemic and understanding during the Covid-19 pandemic. The subject of the research is the S1 PTB Study Program, Civil Engineering Department, Faculty of Engineering, Unesa. This study will review the effectiveness of the lecture model in the PTB Undergraduate Study Program courses between before the Covid-19 pandemic and during the Covid-19 pandemic. The method used in the implementation and data collection of this research is also carried out online through three stages of activities, namely:

a. Preparation, which means compiling a list of the names of the courses carried out in 4 batches of the even semester 2019/2020 academic year and the number of these courses.

b. Data collection, carried out online by the research team and in coordination with all subject lecturers in the S1 Building Engineering Education study program, Department of Civil Engineering, to collect student learning outcomes for 4 generations of academic years, namely 2016/2017, 2017/2018, 2018/2019, and 2019/2020 in courses held in the even semester of 2019/2020 at the PTB FT Unesa S1 Study Program.

c. Data were collected and analyzed quantitatively by percentage. The results of the analysis can be used as a reference to determine the effectiveness of face-to-face and online learning. In addition, to 
determine the readiness of lecturers and students to carry out online learning models or lectures during the Covid-19 pandemic.

\section{Data Analysis Techniques}

Data analysis for this research was carried out by descriptive quantitative percentage. Descriptive analysis to describe the results of data collection on the effectiveness of online lectures, including:

a. The level of understanding of students in face-to-face learning for PTB strata 1 study program subjects before the Covid-19 pandemic was analyzed by: calculating the average student midsemester exam (UTS) scores in each PTB strata 1 course.

b. The level of understanding of students in online lectures for PTB undergraduate study program subjects during the Covid-19 pandemic was analyzed by: calculating the students' average Final Semester Examination (UAS) scores in each PTB strata 1 course.

c. The effectiveness of the lecture model in each course of the PTB strata 1 study program between before the Covid-19 pandemic and during the Covid-19 pandemic was analyzed by: calculating the difference in the mean UTS scores and UAS scores of students in each PTB strata 1 course.

\section{Results and Discussion}

\section{Research Results}

Data collection is carried out through: 1) student learning outcomes obtained from the midsemester exam (UTS) in the application of face-to-face or offline learning; learning is carried out at the beginning of the even semester of the 2019/2020 academic year for approximately 3 months, namely January 2020 to March 2020; 2) student learning outcomes obtained from the final semester exam (UAS) in the application of online learning or learning outside the network (online). Learning is carried out at the end of the even semester of the 2019/2020 academic year for approximately 3 months, from April 2020 to June 2020. In its development, the Covid 19 pandemic is still ongoing, so the implementation of the Work From Home (WFH) and Study From Home learning systems. Home (SFH) via online or online, it is not certain when it will end.

\section{Description of the Average Score of Student Understanding in Face-to-face Learning of the PTB Undergraduate Study Program Before the Covid-19 Pandemic Period.}

\section{a. Average Score of Student Understanding in Face-to-face Learning of the PTB Undergraduate Study Program Before the Covid-19 Pandemic Period}

Data on student understanding of the 2019/2020 academic year towards all courses taken in the 2019/2020 even semester through face-to-face learning in the form of mid-semester exam results (UTS) obtained an average score of 75.78. The average score obtained in the courses: 1) Static Structure Analysis obtained an average of $80.50,2$ ) Calculus with an average of $60.59,3$ ) Integral Digital Literacy an average of 79.62, 4) Low-level Building Construction obtained an average of 65.88, 5) Drawing Civil Buildings obtained an average of 78.79, 6) Material Technology and Practicum obtained an average of $73.18,7)$ Soil Physical Properties with an average of 80.21, 8) Educational Psychology obtained an average of 73.52, 9) School Curriculum with an average of 75.00. 
Table 1. Distribution of Average Student Understanding Scores for the 2019 Academic Year of PTB Undergraduate Courses in Face-to-face Learning Before the Covid-19 Pandemic

\begin{tabular}{|c|c|c|c|}
\hline No. & Course Name & Academic Year & Average Understanding \\
\hline 1 & Static Structure Analysis & 2019 & 80.50 \\
\hline 2 & Integral Calculus & 2019 & 60.59 \\
\hline 3 & Digital Literacy & 2019 & 79.62 \\
\hline 4 & Low Level Building Construction & 2019 & 65,88 \\
\hline 5 & Drawing Civil Buildings & 2019 & 78.79 \\
\hline 6 & Material Technology \& Practicum & 2019 & 73.18 \\
\hline 7 & Soil Physical Properties & 2019 & 80.21 \\
\hline 8 & Educational Psychology & 2019 & 73.52 \\
\hline 9 & School Curriculum & 2019 & 75.00 \\
\hline \multicolumn{2}{|c|}{ Total } & & $\mathbf{7 5 . 7 8}$ \\
\hline
\end{tabular}

Table 1 is the distribution of the average score of student understanding in the 2019 academic year for PTB undergraduate courses in face-to-face learning before the pandemic. Judging from the average price of student understanding in the 2019/2020 academic year for all courses taken through faceto-face learning, it is 75.78 which shows that it is greater than the completeness score of $75.00(\mathrm{M}=75.78$ KKM = 75.00). The price obtained above shows that the students' understanding of the 2019/2020 academic year towards the courses taken through face-to-face learning is good.

\section{b. Average Score of Student Understanding of the 2018 Academic Year of PTB Undergraduate Courses in Offline or Face-to-Face Learning Before the Covid-19 Pandemic Period}

Data on student understanding of the 2018/2019 academic year towards all courses taken in the 2019/2020 even semester through face-to-face learning in the form of mid-semester exam results (UTS) obtained an average score of 77.92. The average score in the subjects: 1) Laboratory Work Workshop Management obtained an average of 79.54 ; 2) Bridge Structure with an average of 77.95 ; 3) Steel Structure (Frame and Portal) average 84.86; 4) Foundation Design and Mektan I with an average of 70.00 ; 5) Learning Evaluation average 78.86. Table 2 is the Distribution of the Average Score of Students' Understanding of the 2018 Academic Year of PTB Undergraduate Courses in Face-to-face Before the Pandemic.

Table 2. Distribution of the 2018 Academic Year's Average Student Understanding Scores on PTB Undergraduate Courses in Face-to-face Learning Before the Covid-19 Pandemic

\begin{tabular}{|c|c|c|c|}
\hline No & Course Name & Academic Year & Average Understanding \\
\hline 1 & Laboratory Workshop Management & 2018 & 79,54 \\
\hline 2 & Bridge Structure & 2018 & 77.95 \\
\hline 3 & Steel Structure (Frame and Portal)) & 2018 & 84.86 \\
\hline 4 & Foundation Design Dr. Mektan I & 2018 & 70.00 \\
\hline 5 & Learning Evaluation & 2018 & 78.86 \\
\hline \multicolumn{2}{|c|}{ Total } & & $\mathbf{7 7 . 9 2}$ \\
\hline
\end{tabular}

Based on the average price of student understanding of the 2019/2020 academic year for all courses taken through face-to-face learning of 77.92, which indicates that it is greater than the completeness score of 75. ( $\mathrm{M}=77.92 \mathrm{KKM}=75.00)$. Overall, it can be concluded, the acquisition of the prices above shows that the students' understanding of the 2018/2019 academic year towards all the subjects they have taken through face-to-face learning has been good. 


\section{c. Average Score of Student Understanding of the 2017 Academic Year of PTB Undergraduate Courses in Offline or Face-to-Face Learning Before the Covid-19 Pandemic Period}

Data on student understanding of the 2017/2018 academic year towards all courses taken in the even semester of 2019/2020 through face-to-face learning in the form of the results of the mid-semester exam (UTS) obtained an average score of 75.77. The average score in the courses: 1) Drawing Buildings Public facilities obtained an average of 71.00; 2) Drawing a Residential House (3D) with an average of 75.75 ; 3) Project Planning and Control obtained an average of 75.97; 4) The design of the building obtained an average of 80.20 ; 5) Entrepreneurship obtained an average of 74.68 ; 6) Vocational Education obtained an average of 73.00; 7) Research Methodology with a mean of 76.38; 8) Learning Planning obtained an average of 79.20 .

Table 3. Distribution of the Average Score of Student's Understanding of the 2017 Academic Year of PTB Undergraduate Courses in Face-to-face Learning Before the Covid-19 Pandemic

\begin{tabular}{|c|c|c|c|}
\hline No & Course Name & Academic Year & Average Understanding \\
\hline 1 & Drawing Public Facilities Building & 2017 & 71.00 \\
\hline 2 & Drawing a Residential House (3D) & 2017 & 75.75 \\
\hline 3 & Project Planning and Control & 2017 & 75.97 \\
\hline 4 & Building Planning & 2017 & 80.20 \\
\hline 5 & Entrepreneurship & 2017 & 74.68 \\
\hline 6 & Vocational Education & 2017 & 73.00 \\
\hline 7 & Research methodology & 2017 & 76.38 \\
\hline 8 & Lesson Planning & 2017 & 79.20 \\
\hline & Total & & $\mathbf{7 5 . 7 7}$ \\
\hline
\end{tabular}

Based on the average price of student understanding in the 2017/2018 academic year for all courses taken through face-to-face learning of 75.77, which indicates that it is greater than the completeness score of 75. $(\mathrm{M}=75.77 \mathrm{KKM}=75.00)$. Overall, it can be concluded, the acquisition of the prices above shows that the understanding of students in the 2017/2018 academic year towards all the subjects they have taken through face-to-face learning has been good.

\section{d. Average Score of Student Understanding of the 2016/2017 Academic Year of PTB Undergraduate Courses in Face-to-face Learning Before the Covid-19 Pandemic}

Data on student understanding of the 2016/2017 academic year towards all courses taken in the 2019/2020 even semester through face-to-face learning in the form of mid-semester exam results (UTS) obtained an average score of 69.00. The average score in the courses: 1) Physical Properties of Soil obtained an average of 69.00 ; 2) The thesis has not obtained the average data; 3) Field Work Practices (PKL) have not obtained the average data. Table 4 above is the Distribution of the 2016/2017 Average Score of Academic Student Understanding of PTB Undergraduate Courses in Face-to-face Before the Pandemic.

Table 4. Distribution of the Average Score of Student Understanding of the 2016 Academic Year of PTB Undergraduate Courses in Face-to-face Learning Before the Covid-19 Pandemic

\begin{tabular}{|c|c|c|c|}
\hline No & Course Name & Academic Year & Average Understanding \\
\hline 1 & Soil Physical Properties & 2016 & 69.00 \\
\hline 2 & Essay & 2016 & - \\
\hline 3 & Field Work Practice (PKL) & 2016 & - \\
\hline \multicolumn{2}{|c|}{ Total } & & 69.00 \\
\hline
\end{tabular}


Based on the average price of student understanding of the 2019/2020 academic year for all courses taken through face-to-face learning of 69.00 which indicates that it is smaller than the completeness score of 75. ( $\mathrm{M}=69.00 \mathrm{KKM}=75.00)$. Overall, it can be concluded that the acquisition of the prices above shows that the students' understanding of the 2016/2017 academic year towards all the subjects they take through face-to-face learning is not good.

\section{Description of the Average Score of Student Understanding in Online or Online Learning During the Covid-19 Pandemic}

\section{a. Average Score of Student Understanding of the Academic Year 2019/2020 Against PTB Undergraduate Courses in Online or Online Learning During the Covid-19 Pandemic}

Data on student understanding of the 2019/2020 academic year for all courses taken in the 2019/2020 even semester through online learning in the form of the final semester exam (UAS) results obtained an average score of 77.04. The average score in the courses: 1) Static Structure Analysis obtained an average of 90.00 ; 2) Calculus with a mean of $69.41 ; 3)$ Integral Digital Literacy obtained an average of 84.18; 4) Low Level Building Construction obtained an average of 68.44 ; 5) Drawing Civil Buildings obtained an average of 79.29; 6) Material Technology and Practicum obtained an average of 74.97; 7) Soil Physical Properties with an average of 77.06; 8) Educational Psychology obtained an average of 75.67 ; 9) School Curriculum with an average of 74.35 . The following is the distribution table for the average score of student understanding in the 2019 academic year towards PTB undergraduate courses in online learning during the pandemic period.

Table 5. Distribution of Average Student Understanding Scores for the 2019 Academic Year of PTB Undergraduate Courses in Online Learning During the Covid-19 Pandemic

\begin{tabular}{|c|c|c|c|}
\hline No & Course Name & Academic Year & Average Understanding \\
\hline 1 & Static Structure Analysis & 2019 & 90.00 \\
\hline 2 & Integral Calculus & 2019 & 69.41 \\
\hline 3 & Digital Literacy & 2019 & 84.18 \\
\hline 4 & Low Level Building Construction & 2019 & 68.44 \\
\hline 5 & Drawing Civil Buildings & 2019 & 79.29 \\
\hline 6 & Material Technology \& Practicum & 2019 & 74.97 \\
\hline 7 & Soil Physical Properties & 2019 & 77.06 \\
\hline 8 & Educational Psychology & 2019 & 75.67 \\
\hline 9 & School Curriculum & 2019 & 74.35 \\
\hline \multicolumn{2}{|c|}{ Total } & & $\mathbf{7 7 . 0 4}$ \\
\hline
\end{tabular}

Based on the average price of student understanding in the 2019/2020 academic year for all courses taken through online learning, it is 77.04 which indicates that it is greater than the completeness score of 75. $(\mathrm{M}=77.04 \mathrm{KKM}=75)$. Overall, the acquisition of the prices above shows that students' understanding of the 2019/2020 academic year towards all courses taken through online learning is good.

\section{b. Average Score of Student Understanding of the 2018/2019 Academic Year of PTB Undergraduate Courses in Online or Online Learning During the Covid-19 Pandemic}

Data on student understanding of the 2018/2019 academic year towards all courses taken in the 2019/2020 even semester through online learning in the form of the final semester exam (UAS) results obtained an average score of 73.32. The average score in the courses: 1) Laboratory Work Workshop Management obtained an average of 75.29; 2) Bridge structure average 70.34; 3) Steel Structure (Frame and Portal) obtained an average of 78.43 ; 4) Foundation Design and Mektan I obtained an average of 66.56 ; 5) Learning Evaluation obtained an average of 76.00. Table 6 above is the distribution of the 2018 
academic year's average student understanding score for PTB undergraduate courses in online learning during a pandemic. Judging from the average price of student understanding in the 2019/2020 academic year for all courses taken through online learning, it is 73.32, which indicates that it is greater than the completeness score of 75. $(\mathrm{M}=73.32 \mathrm{KKM}=75.00)$.

Table 6. Distribution of the Average Score of Student Understanding of the 2018 Academic Year of PTB Undergraduate Courses in Online Learning During the Covid-19 Pandemic

\begin{tabular}{|c|c|c|c|}
\hline No & Course Name & Academic Year & Average Understanding \\
\hline 1 & Laboratory Workshop Management & 2018 & 75.29 \\
\hline 2 & Bridge Structure & 2018 & 70.34 \\
\hline 3 & Steel Structure (Frame and Portal)) & 2018 & 78.43 \\
\hline 4 & Foundation Design Dr. Mektan I & 2018 & 66.56 \\
\hline 5 & Learning Evaluation & 2018 & 76.00 \\
\hline \multicolumn{2}{|c|}{} & & $\mathbf{7 3 . 3 2}$ \\
\hline
\end{tabular}

Overall it can be concluded, the acquisition of the prices above shows that the students' understanding of the 2018/2019 academic year towards all the courses they take through online learning is good.

\section{c. Average Score of Student Understanding of the Academic Year 2017/2018 on PTB Undergraduate Courses in Online or Online Learning During the Covid-19 Pandemic}

Data on student understanding of the 2017/2018 academic year towards all courses taken in the 2019/2020 even semester through online learning in the form of the results of the final semester exam (UAS) obtained an average score of 76.39. The average score obtained in the following courses: 1) Drawing Public Facilities Building an average of 80.00; 2) Drawing a Residential House (3D) with an average of 79.19; 3) Project Planning and Control obtained an average of 65.67; 4) Building design average 80.20 ; 5) Entrepreneurship obtained an average of 73.46 ; 6) Vocational education average 73.53; 7) Research Methodology an average of $81.08 ; 8)$ Perenc Learning obtained an average of 78.00.

Table 7. Distribution of the Average Score of Student Understanding of the 2017 Academic Year of PTB Undergraduate Courses in Online Learning During the Covid-19 Pandemic

\begin{tabular}{|c|c|c|c|}
\hline No & Course Name & Academic Year & Average Understanding \\
\hline 1 & Drawing Public Facilities Building & 2017 & 80.00 \\
\hline 2 & Drawing a Residential House (3D) & 2017 & 79.19 \\
\hline 3 & Project Planning and Control & 2017 & 65.67 \\
\hline 4 & Building Planning & 2017 & 80.20 \\
\hline 5 & Entrepreneurship & 2017 & 73.46 \\
\hline 6 & Vocational Education & 2017 & 73.53 \\
\hline 7 & Research methodology & 2017 & 81.08 \\
\hline 8 & Lesson Planning & 2017 & 78.00 \\
\hline \multicolumn{2}{|c|}{ Total } & & $\mathbf{7 6 . 3 9}$ \\
\hline
\end{tabular}

Based on the average price of student understanding in the 2017/2018 academic year for all courses taken through online learning, it is 76.39 , which indicates that it is greater than the completeness score of 75. $(\mathrm{M}=76.39 \mathrm{KKM}=75.00)$. Overall it can be concluded, the acquisition of the prices above shows that the understanding of students in the 2017/2018 academic year towards all the courses they take through online learning is good. 


\section{d. Average Score of Student Understanding of the 2016/2017 Academic Year of PTB Undergraduate Courses in Online or Online Learning During the Covid-19 Pandemic}

Data on student understanding of the 2016/2017 academic year on all courses taken in the even semester of 2019/2020 through online learning in the form of the results of the final semester exam (UAS) obtained an average score of 67.00. The average score in the subjects: 1) Physical Properties of Soil obtained an average of $67.00 ; 2$ ) The thesis has not obtained the average data; 3) Field Work Practices (PKL) have not obtained the average data.

Table 8. Distribution of the Average Score of Students' Understanding of the 2016 Academic Year of PTB Undergraduate Courses in Online Learning During the Covid-19 Pandemic

\begin{tabular}{|c|c|c|c|}
\hline No & Course Name & Academic Year & Average Understanding \\
\hline 1 & Soil Physical Properties & 2016 & 67.00 \\
\hline 2 & Essay & 2016 & - \\
\hline 3 & Field Work Practice (PKL) & 2016 & - \\
\hline$\quad$ Total & & 67.00 \\
\hline
\end{tabular}

Based on the average price of student understanding in the 2019/2020 academic year for all courses taken through online learning, it is 67.00 which shows that it is smaller than the completeness score of 75. ( $\mathrm{M}=67.00 \mathrm{KKM}=75.00)$. Overall it can be concluded, the acquisition of the prices above shows that the students' understanding of the 2016/2017 academic year towards all the courses they take through online learning is not good.

\section{Description of the Average Score of Student Understanding of PTB Undergraduate Courses by Academic Year in Face-to-face Learning in the Pre-pandemic Period and Online Learning During the Covid-19 Pandemic}

Data on student understanding for the four academic years, covering 2016/2017, 2017/2018, $2018 / 2019$, and the 2019/2020 academic year for all courses taken in the even semester of 2019/2020 through face-to-face learning in the form of the results of the midterm exam (UTS). ) obtained an average score of 75.78. Data on student understanding for the fourth academic year, covering 2016/2017, 2017/2018, 2018/2019, and the 2019/2020 academic year for all courses taken in the even semester of 2019/2020 through online learning in the form of final semester exam results (UAS). obtained an average score of 75.67 .

Table 9. Average Score of Student Understanding Based on Academic Year of PTB Undergraduate Courses in Face-to-face Learning and Online Learning

\begin{tabular}{|c|c|c|}
\hline \multirow{2}{*}{$\begin{array}{c}\text { Academic Year Student } \\
\text { PTB Undergraduate Courses }\end{array}$} & $\begin{array}{c}\text { Average Student Understanding } \\
\text { Face-to-face Learning } \\
\text { (UTS Score) }\end{array}$ & $\begin{array}{c}\text { Online Learning } \\
\text { (UAS Score) }\end{array}$ \\
\hline Academic year 2019/2020 & 75.78 & 77.04 \\
\hline Academic year 2018/2019 & 77.92 & 73.32 \\
\hline Academic year 2017/2018 & 75.77 & 76.39 \\
\hline Academic year 2016/2017 & 69.00 & 67.00 \\
\hline Average of All Courses & $\mathbf{7 5 . 7 8}$ & $\mathbf{7 5 . 6 2}$ \\
\hline
\end{tabular}

Table 9 shows that the average understanding of students in the 4 academic years of all courses taken in the even semester of 2019/2020 through face-to-face learning $(\mathrm{M}=75.78)$ shows the average understanding of students in the four academic years and all courses taken through online learning $(\mathrm{M}=$ 75.62). This means that the average face-to-face learning ( $\left.\mathrm{M}_{\text {face-to-face }}\right)$ is 75.78 , which is greater than the 
average online learning ( $\mathrm{M}_{\text {daring }}$ ) of 75.67. Overall it can be concluded, the acquisition of the prices above shows that the students' understanding of the 2016/2017 academic year towards all the subjects they have taken through face-to-face learning and online learning has been good.

\section{Discussion}

\section{Students' understanding of face-to-face learning before the Covid-19 pandemic}

Department of Civil Engineering, Faculty of Engineering, State University of Surabaya before the pandemic at the beginning of the even semester of 2019/2020 for approximately 3 months, the learning model used face-to-face or outside the network (face to face) for approximately 3 months. In its development, the Covid 19 pandemic occurred so that an online or offline learning system was implemented which was considered an effective solution to overcome the pandemic condition. Face-toface learning is a set of actions designed to support the learning process for students face-to-face by taking into account external events that play a role in a series of events. Face-to-face activities are learning in the form of an interaction process between students and lecturers. Face-to-face activities are learning activities which are also a process of interaction between students, learning materials, lecturers and the environment. Face-to-face learning is still the best and cannot be replaced. In the future, face-toface learning will be further strengthened by the combination of the use of technology.

\section{Student Understanding in Online Learning or Online (Online) PTB Undergraduate Study Program During the Covid-19 Pandemic}

Online learning or online learning is defined as an effort to connect learners (students) with their learning resources (databases, experts/instructors, libraries) who are physically separated or far apart but can communicate, interact or collaborate directly (directly/sJnchroooos and indirectly/async/7roooos). Online is a form of distance learning that utilizes telecommunications and information technology, such as internet, video/audio broad casting, video/audio conferencing, CDROOM (directly and indirectly) to all electronic media, the aim is to help students to better master the learning material. horse. Online means learning to use electronic device assistance services directly. The activities are included in the individual learning model. Online learning has great potential because students and lecturers can access material widely from various sources. Thus, online learning can be defined, namely: delivery of learning materials through electronic media such as the internet, intranet/extranet.

The online system is an internet-based distance learning which uses learning devices with online application media such as Zoom, Whatsapp, Google Classroom, Edmodo, Google Meet, and others. In its implementation, learning with this system requires an internet network and data packages because it focuses on the implementation of E-Learning, this system clearly provides convenience for students and teachers. From the students' point of view, they don't need to carry many thick and thick books to learn a material, just search and download e-books or learning videos they can easily learn anytime anywhere without fear of losing or missing the material because it can be stored. As for the teacher, the teacher is not always the benchmark for learning resources so that students are given the opportunity to learn independently, the learning system is flexible, and the teacher can increase innovation in presenting material content to students.

\section{Conclusions}

Based on the results of this study, it can be concluded that the level of student understanding in face-to-face learning of PTB Undergraduate Study Program courses before the Covid-19 pandemic was good. In addition, the level of student understanding in the application of online lecture learning to PTB Undergraduate Study Program courses during the Covid-19 pandemic is quite good. The platform used in online learning is carried out with various applications, including whats app, google classroom, zoom, 
google meet, and so on. The choice of this platform is adjusted to the type of course and has been communicated with students. The level of effectiveness of the lecture model in the PTB Undergraduate Study Program courses between before the Covid-19 pandemic and during the Covid-19 pandemic.

From the conclusions that have been obtained, recommendations can be given so that the online lecture learning model is more effective in implementing learning during the pandemic, it is necessary for lecturers and students to be prepared to use various online applications that greatly contribute to a smooth teaching and learning process in the PTB Undergraduate Study Program Department. Civil Engineering, Faculty of Engineering, State University of Surabaya. Online learning is likely to continue in the future even after the pandemic period has ended. It is recommended for lecturers and students to always develop the ability to be able to apply various technologies with the emergence of various applications for remote meetings that are smoother, easier and cheaper.

\section{References}

Cakir, H. (2013). Use of blogs in pre-service teacher education to improve student engagement. Computers \& Education, 68, 244-252. https://doi.org/10.1016/J. COMPEDU.2013.05.013

Creswell, J. W. (2012). Educational Research: Planning, Conducting, and Evaluating Quantitative and Qualitative Research. London \& New York: Pearson Education. Gheytasi.

Harto, K. (2018). Tantangan Dosen PTKI di Era Industri 4.0. Jurnal Tatsqif, 16(1), 1-15. Retrieved from http://journal.uinmataram.ac.id/index.php/tatsqif/article/view/159 Israel, S. E. (n.d.). Metacognition in Literacy Learning Theory, Assessment, Instruc-tion and Professional Development. Mahwah: Lawrence Erlbaum Associates, Inc.

Keengwe, J., and Georgina, D. (2012). The digital course training workshop for online learning and teaching. Education and Information Technologies, 17(4), 365-379. https://doi.org/10.1007/s10639011-9164-x

Putrawangsa, S., and Hasanah, U. (2018). Integrasi Teknologi Digital Dalam Pembelajaran di Era Industri 4.0. Jurnal Tatsqif. 16(1), 42-54. $\quad$ Retrieved from http://journal.uinmataram.ac.id/index.php/tatsqif/article/view/203

Rahman Sidek, E. A., \& Md. Yunus, M. (2012). Students' Experiences on using Blog as Learning Journals. Procedia-Social and Behavioral Sciences, 67, 135-143. https://doi.org/10.1016/J.SBSPRO.2012.11.314

Circular Letter. Ministry of Education and Culture. Lembaga Layanan Pendidikan Tinggi (LLDIKTI) Wilayah VIINomor : 701/LL7/AK/2020 Tanggal 13 April 2020

Wekke, I. S., and Hamid, S. (2013). Technology on Language Teaching and Learning: A Research on Indonesian Pesantren. Procedia - Social and Behavioral Sciences, 83, 585-589. https://doi.org/10.1016/J.SBSPRO.2013.06.111

\section{Copyrights}

Copyright for this article is retained by the author(s), with first publication rights granted to the journal.

This is an open-access article distributed under the terms and conditions of the Creative Commons Attribution license (http://creativecommons.org/licenses/by/4.0/). 